\title{
POR QUE NÃO A VIOLÊNCIA?
}

\author{
Rejane Batista Vasconcelos \\ Universidade Federal do Ceará (UFC) \\ Faculdade Metropolitana da Grande Fortaleza (Fametro)
}

\section{POR QUE NÃO A VIOLÊNCIA?}

Resumo: O artigo é parte constitutiva de minha tese de doutorado que se ocupou em demonstrar que a violência, uma ação exclusivamente humana e tão antiga quanto o ato inaugural da humanidade, representa tão-somente, no sistema do capital, uma entre todos os milhares de mercadorias que se colocam à disposição nas prateleiras do mundo mercantil. Sob intensidade e forma variadas, a violência encontra-se implícita ou categoricamente derramada por sobre as múltiplas manifestações de criação humana, tais como a arte, a religião, a literatura, a política, a história. É um produto que parece contrariar as leis do mercado: quanto mais abundado mais lucrativo!

Palavras-chave: Violência, mercadoria, Capital, sistema do capital.

\section{WHY NOT VIOLENCE?}

ABSTRACT: The article is a constitutive part of my doctorate thesis which busied itself in showing that violence, an exclusive human action and as old as the initial act of mankind, represents only, in the capital system, one among thousands of commodities that put themselves disposable on the shelves of the merchant world. Under different intensity and shapes, violence is found implicitly or categorically spilled in multiple human creative expressions, such as art, religion, literature, politics and history. It's a product that seems to contradict the market laws: the more plentiful it is, the more profitable it seems to be.

Keywords: Violence, commodity, Capital, capital system. 
1 INTRODUÇÃO: sobre violência convém saber

Se conseguirem que você faça as perguntas erradas, eles não têm de preocupar-se com as respostas. (Pynchon, Thomas)

O que é violência? Eis uma pergunta nem certa nem errada, talvez. Mas, ainda assim, impõese correção nas respostas. Tomando com a devida severidade a observação feita pelo autor da frase em epígrafe, percebe-se que ainda se está longe de ver demonstrada a necessária preocupação para com as respostas ofertadas, ou pelo menos não se tem levantado preocupação com o impacto que as respostas a essa indagação causam ou deixam de causar na sociedade.

Há quem diga simplesmente que a violência é intrínseca ao ser humano. Há quem fale ser a violência uma pulsão de morte que se opõe à de vida. Há quem a pense um processo que impulsiona mudanças. Uns a definem como não - razão. Pensam e argumentam outros que no ato violento a razão não se esvai, que, portanto, se trata de um ato intencional. Alguns a ela se referem como um processo; outros a classificam como meio. Confundem-na com o conflito, tomando este por aquela como se ambos fossem expressão de um só fenômeno. Endeusam-na e cantam-na na arte. Introduzem-na bem cedo, lúdica e sutilmente no cotidiano das crianças, ensinando-lhes e a todos a torná-la banal por meio das canções de ninar, dos personagens de desenhos animados, dos filmes infantis veiculados nas manhãs e nas tardes nos variados e mesmos canais de TV.

Tornam-na mais pulsante e sangrenta na mostra farta e diversificada com que é diuturnamente levada com licenciosidade aos lares de todos, por meio dos noticiosos policiais que ocupam as programações locais e nacionais. Uma marca que deixou de ser peculiar a essa programação específica e invadiu o espaço dos noticiosos outros que, outrora, se distinguiam do caráter sanguinolento e espetaculoso dos primeiros. Houve um tempo não saudoso! - em que o sangue derramado nos atos violentos só ocupava os telejornais quando nele havia um componente político ou quando a crueza do evento que o fizera fluir da veia carecia da indignação coletiva. Tal não é o que hoje se flagra. As questões políticas, as econômicas, as sociais coagulam-se no vazar abundante do sangue dos embates cotidianos capturados pelo foco da lente do cinegrafista profissional - ou não mais - cioso, sedento tanto por invadir a retina vívida do algoz quanto o já nublado olhar que, no corpo pardacento e inerte que agora jaz como ilha rubra, ficou congelado. Há um esforço inumano para fazê-lo dizer de sua dor; para arrancar de suas vísceras um ai; para vender essa cena; para trocá-la por audiência. Pena que esse corpo já não mais geme; que lastimável não se poder registrar cada ai já inaudível, que denuncia o fim! Lamentável não se conseguir fazer de cada ai numerário!

O espetáculo brutal cada vez mais automatizado, descolado, corporificado torna-se vendável quer em versões completas, quer sob forma seriada ou na modalidade compactada. O modo como esse espetáculo é posto em evidência garante audiência, sucesso, por consequência lucro.

Há que se reconhecer um quê de fascínio instalado no espetáculo 11 de setembro: as torres ruindo e ressurgindo infindamente. Uma violência que sem dúvida deixou nossos olhos atentos, nossos músculos retesados, nossa mente vígil.

Naquela manhã de setembro que se inaugurara comum, o inesperado iria irromper. Tudo o que parecia, há bem pouco, imponderável, aquelas toneladas de aço acabavam de fazer: foram de encontro ao símbolo do capitalismo mundial; puseram-no no chão, macularam-no, tingiram-no com o sangue dos seus e o de estranhos. Embora inelutavelmente reprovável, desse ato terrorista lampejava um quê de simbólico, tanto é assim que Bush, logo após a tragédia, aproveitando a plateia mundial, e como que a convocando para uma revanche, brada: O coração do mundo foi atingido.

Aquele evento congelado, plasmado, passava a apresentar-se absolutamente ausente de conexão factual. E, pelo mundo, chorava-se, velava-se, horas e dias a fio, por cada um e por todos aqueles conhecidos e anônimos homens e mulheres que, infelizmente, pisavam, distraidamente, naquele dia e hora, 0 coração do mundo. E o mundo gelado pelo horror mantinha seus olhos, corpos e emoções congelados pela mesma imagem que, a cada vez, parecia outra.

$\mathrm{Na}$ cena reprisada, que, com ânsia, se aguardava, surgiriam novos detalhes, antes despercebidos; detalhes que escaparam e que poderiam ser imagéticos ou que se acresciam - ou eram mesmo criados - na locução de um profissional. Tudo fazia daquela cena uma nova cena. Incessantemente reinaugurava-se, refundavase 0 ato irascível, imobilizador. Uma aura, uma mágica se colocava em torno daquela ocorrência estarrecedora. A violência do espetáculo imantava, imobilizava; fazia ouvidos gritos e gemidos, mas produzia, ao mesmo tempo, a mudez angustiante, estranha, sufocante.

Diante do espetáculo do World Trade Center um incontestável horror -, o mundo não mobilizaria as mesmas emoções no mesmo grau e intensidade acaso tivesse tão-somente tomado conhecimento do ocorrido, em vez de ter assistido a ele de seu escritório, de sua sala, de seu sofá, de sua cama, daí a importância de um espetáculo cuidadosamente produzido, trabalhado. A depender do espetáculo que em torno de um fato se instale, sua gravidade pode ser inferiorizada ou maximizada: ela é menor ou maior, menos ou mais impactante a depender da luz que lhe jogam, do tempo em cena que the confiram, do investimento que nele façam. 
Como salienta Debord (2007, p. 44),

O espetáculo não exalta os homens e suas armas, mas as mercadorias e suas paixões. É nessa luta cega que cada mercadoria, ao seguir sua paixão, realiza de fato na inconsciência algo mais elevado: o devir-mundo da mercadoria, que também é o devirmercadoria do mundo.

Não parece que tenham sido os milhares de incautas vítimas soterradas, naquela manhã fatídica, no coração do mundo, a dar o tom do espetáculo, mas sim a audácia traduzida no ato de flechar aquele pétreo coração inatingível, até então, incólume, simbolizador do poder econômico. Mas a tragédia transfigurada espetáculo, naquele primeiro ano do século $X X I$, fez-se eternizada nos instantes todos que se seguiram ao desatinado voo da morte. E novamente tomo a fala de Debord (2007, p. 28, 30) para ofertar uma tradução, para lançar um olhar sobre o 11 de setembro:

O mundo presente e ausente que o espetáculo faz ver é o mundo da mercadoria dominando tudo o que é vivido. $\mathrm{E} O$ mundo da mercadoria é assim mostrado como ele é, pois seu movimento é idêntico ao afastamento dos homens entre si e em relação a tudo que produzem. [...]. O espetáculo é o momento em que a mercadoria ocupou totalmente a vida social. Não apenas a relação com a mercadoria é visível, mas não se consegue ver nada além dela: o mundo que se vê é o seu mundo.

A violência - atestam não apenas os estudiosos - é um ato humano que se inaugura com a estreia da humanidade. A ela, indevida e intencionalmente, faz-se aderida a predicação inerradicável, ineliminável, inelutável, inextinguível. Às vezes também - e não raro - dela se disse uma alternativa à ameaça do estado de inércia social. $\mathrm{O}$ fato é que a violência e os temas a ela correlatos têm, desde as últimas décadas do século $X X$, irrompido com relevância nos estudos de distintas ciências, disciplinas. Saberes e dizeres em torno da questão se adensam e ampliam-se. Há uma sede inesgotável de sobre ela saber e discorrer. Cada vez que um ato assim qualificado faz-se acontecido, ele se torna verbo; produz uma fala amplificada, diversificada, abundante. Inumerável é a produção técnica, científica, literária, que se encontra no circuito de venda, cujo foco direto ou indireto é essa temática. Cada obra dessas que se toma nas mãos para leitura referencia um número significativo de outras produções.

Uma questão, aqui, emerge: o fato de um ato humano de tão grave repercussão, que tem lançado sobre si tanta preocupação, ser, a um só tempo, naturalizado e estranhado. São processos que, à primeira vista, soariam inversos, paradoxais. Não o são, no entanto. São tão-somente, um do outro, complemento. Naturaliza-se a violência para com ela se conviver, para garantir sua existência; existindo, instala-se contra ela um combate no qual ela não se faz derrotada. Se natural, humana, inextinguível, ineliminável, inelutável, inerradicável, o que resta a fazer é apenas encontrarem-se formas adequadas de com ela conviver, modos de enfrentamento apropriados. Não havendo, pois, sob tais argumentos, alternativas possíveis para o seu extermínio, posto que sua eliminação configura expressão de si mesma - de violência. É intrigante essa naturalização e esse estranhamento como um lusco-fusco da violência.

Indiscutivelmente, a violência consolida um estado perene de medo. Basta que sejam trazidos à memória resultados de levantamentos, enquetes, pesquisas de opinião veiculados na mídia acerca do que a população mais teme. A violência se classifica como, senão a primeira, pelo menos uma das primeiras causas de inquietação, de insegurança, de temor enfim.

Assim sendo, por que ordem de razão ela haveria de se inserir abusivamente no cotidiano das pessoas? Por que, sob outras formas de apresentação, com outros invólucros a ela se confere outro estatuto, outro status: o de produto comercializável? Películas cinematográficas, músicas, videoclipes, games, revistas, livros, desenhos animados, programas de entretenimento veiculados na mídia televisiva, destinados a públicos vários e faixas etárias distintas, recheiamse de cenas em relação às quais não paira dúvida alguma quanto a reservarem um conteúdo violento, quando não são exclusivamente configurados com a finalidade crua de apresentar a violência mesma.

É irrefutável: a violência invade, com licenciosidade, os espaços, os corpos e as mentes dos sujeitos na razão direta em que aquece os medos e acelera as fomes de justiça, de vingança, de paz, de guerra. O mais assustador é que - como já disse - o aprendizado da violência inaugura-se precocemente: na audição de cançõezinhas com que se embalam os bebês (Boi da cara preta, Atirei o pau no gato, Sambalelê está doente) ou de historinhas que distraem e estimulam a imaginação e o aprendizado das crianças (Branca de Neve, Joãozinho e Maria); na audiência de desenhos animados (Tom e Jerry, Piu-Piu e Frajola). Passando depois pelos games em que o jogador para alcançar maior pontuação deve atropelar o maior número de velhinhos, ou matar mais inimigos; por programas destinados ao público juvenil (Malhação); por assistência, submissão ou prática de bullying nas escolas, nos grupos sociais - agora, com as cenas capturadas por celulares e divulgadas nas redes sociais. O fato é que o aprendizado se renova, atualiza-se, ganha forma, requinte, cor e 
tom sedutores. Aos adultos também fica garantido um sempre renovado estoque de táticas de vileza, crueldade, ardileza e intolerância na audiência de telenovelas nos diversos horários e emissoras.

Já os reality shows põem, sem censura alguma, sob experimentação os limites físicos, emocionais e morais dos sujeitos participantes, em troca de um prêmio que quase sempre suplanta em muito a renda anual de cada um de seus integrantes.

Um exemplo nacional dessa modalidade de audiência - em tempo real - de cenas de violência transfiguradas em entretenimento em que todas as tarefas a serem cumpridas pelos participantes eram de esforço físico intenso, de sujeição a desgaste, tensão, privação, constrangimento, estresse físico e mental foi o No limite, produzido pela TV Globo. O prêmio era de quinhentos mil reais.

Outro reality, Solitários, foi produzido pelo SBT. O reality apresentava-se com a "promessa de levar os participantes à total exaustão". Todos permaneciam isolados e incomunicáveis em um pequeno compartimento individual sem acesso à luz solar, sem direito à cama, privados de cuidados higiênicos básicos como banho e troca de roupa. Para deitar-se, sentar-se ou utilizar o banheiro o participante teria que pedir autorização prévia. Saliente-se que esse reality foi o que deu o menor prêmio: cinquenta mil reais em barras de ouro.

Que objetivo subjaz a essa massiva apresentação de espetáculos de violência?

Presumo que não pareça ao leitor precipitada ou infundada a ideia, que já deixo aqui defendida, de que nenhum outro modo organizativo de sociedade, que não o vigente no sistema do capital, permitiria à violência despontar com esse caráter mercantil, com esse potencial de transfigurar-se em riqueza. A origem mesma do capital, já o denunciava Marx (1973), tinge-se de rubro. E no rubro faz-se ouro! A violência é matriz do capital; por seu meio, ele se gesta, mantém-se, multiplica-se.

Ela é, desde muito, mercadoria: eis o ponto de partida. Ao ingressar no circuito do mercado, passou por uma intensiva mercadização. É de fácil "comercialização". É rentável, de baixíssimo risco e de garantia de elevados lucros. Como, então, não a situar sob a égide do dinheiro, na lógica do lucro, com base na estética fundada no metal, no universo regido pelo capital? Como, pois, não traduzir seu suposto combate como um encantador embute, visto que, em são consciência, não se destrói uma inesgotável fonte de lucro certo?

Haveria, na civilização do capital, razão plausível para se combater a violência? Eis por que se deve buscar a pergunta certa.

Não há como subestimar esse dado de realidade: a violência concreta, sólida, liquefeita ou rarefeita assombrosamente tem se derramado por sobre tudo e todos como um fantasma de que não se pode fugir. O capital é sua metáfora mais sólida.

\section{A VIOLÊNCIA: um fenômeno de "pseudovoz"}

Compreender aquilo a que estamos fadados significa estarmos conscientes de que isso é diferente de nosso destino. $\mathrm{E}$ compreender aquilo a que estamos fadados é conhecer a rede complexa de causas que provocam essa fatalidade e sua diferença daquele destino. Para operar no mundo (por contraste a ser "operado" por ele) é preciso entender como o mundo opera. (Bauman, Zygmunt)

A ossatura da ideia de violência como mercadoria foi-se constituindo, ganhando vulto à medida que, num exercício mental rápido, dei conta de que em múltiplas formas de criação, de relação e de expressão humanas ela vinha como elemento integrativo, quer essencial, básico, quer acessório, tangencial.

Entranhada no cotidiano das pessoas de forma quase irrecusável, quaisquer que sejam sua intensidade, sua frequência, sua expressão, sua modalidade, a violência é, a um só tempo, dor e prazer, pesar e lazer, como comprova o psiquiatra forense Simon (2009, p. 20), quando afirma:

Ficamos aterrorizados e, ao mesmo tempo, fascinados pelo lado obscuro do ser humano. Milhares de cidadãos respeitosos são ávidos consumidores de filmes, programas de televisão, vídeos, livros e artigos que falam de assassinato, estupro e outras formas de violência. [...]. De cada oito filmes produzidos em Hollywood, um tem como tema o estupro. Quando o norteamericano médio chega aos 18 anos de idade, já assistiu a 250 mil atos de violência, incluindo 40 mil assassinatos, na televisão. [...]. Autores de livros de mistério podem contar com boas vendas se explorarem a tese de que quase todas as pessoas podem ser levadas a matar.

Simon (2009), nessa obra, visa fundamentalmente demonstrar que é necessário que se suspenda a ideia dicotômica que classifica as pessoas em boas e más. E que, ao contrário, todas as pessoas deveriam reconhecer-se dotadas de um lado sombrio capaz dos mais condenáveis atos, até como forma de municiar-se de mecanismos de controle, freios. E arremata dizendo que Os impulsos antissociais das pessoas são oportunistas (SIMON, p. 2009, p. 22). Acrescento: e oportunidade é o que o mercado não deixa escapar!

$O$ fato é que a violência que se combate é a mesma que é alimentada, proclamada: a quantos não foi prescrita certa dose de violência necessária à sobrevivência do dia a dia? Sob que formas sutis e explícitas a violência tem sido abertamente 
veiculada como entretenimento por meio de filmes, seriados, telenovelas, desenhos animados, programas infantis, vale-tudo (lutas), revistas eletrônicas matinais, vespertinas ou noturnas, diárias ou semanais, programas de variedades que trazem à mostra dores íntimas, dramas pessoais e familiares? Em telejornais e programas estritamente policiais, que informações acerca de violência são veiculadas? De que modo, com que frequência e intensidade isso se dá?

A violência, inquestionavelmente, tornouse um produto posto nas prateleiras do mercado sob várias formas de apresentação, dosagem, invólucros, segundo o gosto e o poder aquisitivo do consumidor. E a segurança - seu anverso, a outra face dessa moeda -, que se convencionou a forma de seu combate, igualmente, expande-se, diversificase e enche cofres de quem soube - e sabe -, além de fazer a pergunta certa, oferecer uma resposta errônea para os demais que fizeram - e vêm fazendo - a pergunta equivocada acerca de por que se está a experimentar tanto a expressão real, concreta da violência, quanto o estado perene de medo que ela instaura. Como nos alertava o autor da epígrafe com que abri este artigo, o esforço de quem lucra com a violência e seu pseudocombate é voltado para que não se consiga elaborar uma pergunta precisa, correta, cuja resposta faça todos entenderem o que a violência instaura para o sistema do capital. Eis o nó górdio a ser desatado!

Os sujeitos devem sentir-se instados a indagar: Por que esse sentimento de impotência diante da violência? Por que esse mesmo sentimento em relação à espetaculização da violência? Por que a violência e seus produtos tornam-se agudamente invasivos? Deve ser tarefa coletiva formular indagações dessa ordem.

Deveria parecer intrigante o fato de a violência fazer parte constitutiva da trajetória humana, de responder pelo modo como se organizam os traçados geográficos, políticos, sociais, econômicos, culturais, morais das sociedadese, ao mesmo tempo, levantaremse vozes e conclamarem-se homens e mulheres à marcha por seu extermínio. E mais intrigante ainda deveria parecer o fato de se dizer que é da natureza humana usar de violência, ser violento, como forma de explicar o caráter inerradicável, ineliminável, inelutável, inextinguível que se lhe atribui.

Em Arendt (1985), vê-se derrubada esta tese, a partir de quando ela argúi que violência não é processo; é meio. Defende a autora que é da impotência que emana a violência e não do poder, como se costuma inferir.

Pensando, como Arendt (1985), que violência é meio, torna-se possível defender a ideia de que violência é uma entre outras tantas desembocaduras a que uma situação de conflituosidade pode ser levada. Sendo, pois, meio, recurso, instrumento, um outro meio, um outro recurso, um outro instrumento poderia ser capaz de a substituir. Por que tal não ocorre? Eis mais uma questão que merece ser posta em debate.

Costa (2003, p. 39) apresenta violência como "[...] o emprego desejado da agressividade, com fins destrutivos." Acusa a psicanálise de tratar "[...] da violência diluindo seu impacto e atenuando seu horror." Argumentado que, ao conceber violência como sinonímia de morte, sacraliza-a; ao lhe conceder o estatuto de "[...] condição de possibilidade natural' do existir humano." Banaliza-a (COSTA, 2003, p. 18).

Costa (2003) toca, sem luva, uma chaga que poucos têm ousado, pelo menos, dizê-la existente: a inarredável natureza perversa contida nas expressões de violência. É de importância irrefutável o que o psicanalista denuncia: a naturalização com que as falas abalizadas e alguns grandes estudos vêm enfocando um problema configurado como algo intrínseco à condição humana, como o é, de fato, no que concerne a sua realização, mas não no que diz respeito a sua inevitabilidade, pelo menos sob outra égide que não a do capital. Humano, sim, porquanto desejado, mas passível de eliminação de algumas de suas formas, de redução, de subtração porquanto ser um meio, como nos advertiu Arendt (1985). Se meio é a violência, um outro meio a substitui.

Como e por que a violência assume essa condição de inextinguível, ineliminável, inerradicável, inexpugnável?

\subsection{Violência e Conflito: a indistinção como embuste}

Chamo a atenção, aqui, para um aspecto, grosseiramente, descuidado - diria, na melhor das hipóteses, um equívoco -, flagrante nas falas de alguns estudiosos da violência: a indistinção entre conflito e violência. Não raro, violência e conflito são termos tomados por iguais, como se fosse um, do outro, sinônimo. Atribui-se a eles um mesmo status, ao tratá-los como um mesmo evento, como um fenômeno único. Presumo que grande parte dos emaranhados teóricos enraíze-se nesse terreno: tomar meio (violência) por processo (conflito) e vice-versa.

Se é possível e absolutamente próprio falarse da existência do conflito interior, isto é, aquele vivenciado por todos os - e cada um dos - sujeitos no que tange as suas questões internas, não se torna possível, então, pôr obstáculo à aceitação de que o conflito esteja colado à condição humana.

O sujeito, na condição de portador de um conflito inaugural em uma situação com outrem, funda e refunda velhos e novos conflitos com faces e dimensões múltiplas, e de motivações e encaminhamentos vários.

Os conflitos ganham forma e expressão em todos os espaços, por todo o tempo, e inscrevem como seus autores e atores todos os sujeitos, indistintamente. Os conflitos assumem papéis e atuam como definidores de outros traçados do cenário social. 
Essa natureza infindável e latente do conflito, Coser (1996, p. 123) reconhece-a:

O conflito é parte inerradicável da vida conjunta dos seres humanos; é um componente tão fundamental da associação quanto a cooperação. $O$ que é factível, porém, é transformar tipos específicos de comportamento de conflito quando estes são entendidos como antifuncionais ou nocivos.

Pasquino (2004, p. 228) corrobora a mesma ideia:

De fato, todo conflito é ínsito na mesma configuração da sociedade, do sistema político, das relações internacionais. Ele resulta em elemento ineliminável que conduz à mudança social, política, internacional. Ineliminável em longo prazo, porque a curto e médio prazo, o conflito pode ser sufocado ou desviado.

O que, então, constituiria o conflito? Um conflito, uma situação conflituosa, envolve desde uma falta de entendimento entre duas ou mais partes, uma discussão acalorada, um choque, um enfrentamento, uma discordância no concernente às competências, às jurisdições dessa ou daquela autoridade, a um conflito diplomático que desemboque no plano do enfrentamento físico e com o emprego de armas. São as definições encontradas em Houaiss (2001, p. 797) para o vocábulo conflito.

O lexicógrafo oferta, ainda, a significação de distintas expressões em que o conflito se vê inaugurado: conflito de atribuições, conflito de competências, conflito de direitos, conflito de interesses, conflito de jurisdição, conflito de jurisprudência, conflito de poder, conflito de provas, conflito de trabalho, conflito intrapsíquico, mental ou psíquico. Não se esgotam nessas formas elencadas na citada obra as expressões inúmeras que toma o conflito tanto na arena social como no foro íntimo.

As definições que, no campo das ciências sociais, autores vários põem para o conflito não recusam sua natureza interativa, quer se instale o conflito entre os indivíduos, quer entre grupos, organizações ou sociedades.

Coser (1996, p. 120-121), acerca de conflito, diz:

Definido como uma contenda a respeito de valores, ou por reivindicações de status, poder e recursos escassos, na qual os objetivos das partes conflitantes são não apenas obter os valores desejados mas também neutralizar seus rivais, causar-Ihes dano ou eliminá-los, o conflito pode ocorrer entre indivíduos ou entre coletividades. Esses conflitos intergrupos, bem como intragrupos, são aspectos perenes na vida social.
Em Étienne et al. (1998, p. 78), se vai encontrar conflito com a significação de

[...] expressão de antagonismos abertos entre os indivíduos ou grupos para a pesquisa, a posse ou a gestão de bens materiais ou simbólicos (riqueza, poder, prestígio, etc.), sendo o objectivo de todo o conflito a modificação das relações de força.

Em Estudios sobre las formas de socialización, Simmel (1977, p. 265) afirma, acerca do conflito, que

\begin{abstract}
Si toda acción recíproca entre hombres es una socialización, la lucha, que constituye una de las mas vivas acciones recíprocas y que es lógicamente imposible de limitar a un individuo, ha de constituír necesariamente una socialización.
\end{abstract}

Acrescenta ainda esse filósofo, historiador e sociólogo alemão que os conflitos decorrem do ódio, da inveja, da necessidade, da riqueza - definindo esses elementos como dissociadores, provocadores da apartação. Diz, ademais, que da dissociação seria dado cabo através da luta, esta "[...] una via para llegar de algún modo a la unidad, aunque sea por el aniquilamiento de uno de los partidos" (SIMMEL, 1977, p. 265).

Também para Marx, o conflito é elemento de unificação. O conflito de interesses proporciona a consciência de classe para si, que termina por assegurar a condição de pertença. E, como disse, a identidade do grupo se forja na experimentação do antagonismo e na sua expressão dramática - a luta (MARX apud COSER, 1967).

No Manifesto do Partido Comunista, Marx e Engels (s.d.) asseveram que a história de todas as sociedades inscreve-se na - ou confundese com a - história das lutas de classes. E mais, que, nas sociedades capitalistas, polarizam-se classes sociais, ficando elas, assim, continuamente postas em situação de conflito. A luta de classes torna-se cada vez mais recrudescida, à medida que o capitalismo se desenvolve. Desse modo, da luta de classes - o conflito central - acaba derivando o conjunto de fenômenos sociais. E Marx (2008, p. 33) afirma ainda que, "[...] se o nosso fim, a socialização das forças produtivas, é uma necessidade econômica, o nosso auxiliar, a força, é uma necessidade histórica". Reafirmando sua defesa em prol da luta, argumenta que "todos os progressos humanos, todas as transformações sociais e políticas da nossa espécie têm sido obra da força" (MARX, 2008, p. 33).

Gostaria de destacar, entre os vários autores estudados, Morillas (2003), que também qualifica conflito como forma de interação social, como parte constitutiva do processo de socialização 
entre indivíduos, como fonte de criatividade e de renovação contínua, mas que ressalva que o conflito também pode produzir resultados aniquiladores, destrutivos.

Inúmeras são as concepções acerca dessa forma de interação social, o que torna impossível expô-las em um artigo. E, assim como a violência, o conflito também não alcança unanimidade conceitual.

Embora até não se veja reservada totalidade de convergência no tocante à temática da violência, nas obras de Arendt (1985), Costa (2003) e May (1981) - autores que edificaram os alicerces, as pilastras do estudo realizado -, fica impressa a certeza de que violência constitui meio, instrumento, jamais processo.

Para May (1981, p. 148), a violência deve ser entendida como "[...] uma explosão do impulso para destruir o que é interpretado como uma barreira ao amor-próprio, ao movimento e ao crescimento." Adverte que, apesar da violência ser "[...] predominantemente um evento físico," ela "[...] ocorre num contexto psicológico." (MAY, 1981, p. 149).

O autor inaugura seu texto dizendo que "[...] o poder é essencial a todas as coisas vivas." (MAY, 1981, p. 17). E adiante ele assinala que a profusão de discursos emanados, sobretudo na década de 1980, acerca do poder do indivíduo de adquirir, de produzir significado político ou psicológico, traduzia nada mais que um esforço de compensar algo de que se estava a sentir a falta. Para ele, o poder e o sentimento de significação se interligam: "[...] um constitui a forma objetiva e o outro a forma subjetiva da mesma experiência." E seria a perda da sensação de significação (MAY, 1981, p. 31) que faria o indivíduo lançar mão das outras formas de poder que repercutem sob a modalidade de agressão e violência.

A materialização da violência revela a falência ou insucesso em concretizar a sensação de significação por meio dos recursos disponíveis nas fases ou níveis anteriores de poder. Eis a razão por que, diz May (1981, p. 37 - 38), a violência é predominantemente física: "[...] porque as outras fases, que podem envolver argumentação ou persuasão, foram ipso facto bloqueadas."

Falas de outros autores encontram ressonância na afirmativa de Arendt (1985, p. 29) de que "[...] à violência sempre é dado destruir o poder; do cano de uma arma desponta o domínio mais eficaz, que resulta na mais perfeita e imediata obediência".

Com as falas, aqui, expressas, ganha nitidez a diferenciação entre o que é conflito - um processo ineliminável, inexaurível na sociedade - e o que configura a violência - um meio através do qual pode ser dado termo a um conflito. Daí a urgência em suspender, em suprimir a predicação de inevitável, ineliminável, inelutável, irrecusável que foi atribuída ardilosamente à violência. Na realidade, o que tem essa predicação é o conflito - que é um processo -, não a violência - que é um meio, um recurso, entre outros, como a diplomacia (um seu oposto), para por termo ao primeiro.

Tomar violência como sinonímia de conflito este sim inerradicável - é o modo mais vil de que se vale o sistema capitalista para auferir lucros sobre uma mercadoria tão singular: quanto mais abundante mais lucrativa.

O que redunda do entendimento, da aceitação da violência com essa natureza? O resultado é a imposição, a imprescindibilidade da convivência com sua contraversão: a segurança - entendida como a aquisição de produtos, bens e serviços de empresas que constroem e expandem seu patrimônio a expensas da violência e de seu propalado - ou real - crescimento. É uma relação precisa, sonante: se a violência é inevitável, a segurança - a busca por segurança - também o será. Logo, quanto maior a violência, maior a oferta dos serviços classificados como de segurança.

Paralelamente à franca expansão do mercado da violência, o mercado da segurança, seu espelho, apresenta-se como solução ao sentimento real e forjado de medo, de intranquilidade, de pavor. O fato é que a mercadização da violência, do medo, da intranquilidade ganha terreno, auferindo lucros e assegurando fontes sempre renovadas de rentabilidade, quer a violência in natura, quer a que se espetaculiza, quer a transfigurada em segurança. Em todo espaço, a qualquer instante, qualquer um pode verificar a invasão da propaganda de serviços e equipamentos de segurança, seja na mídia impressa, televisiva, radiofônica, digital. Cada produtor, a seu modo, seduz o comprador.

Mas dois paradoxos gritam, saltam à vista nessa equação: primeiro, se a prometida segurança - os serviços, bens e produtos dessa cesta -, produzisse resultado, a violência estaria num descenso. Por que, então, cresce o número de empresas desse ramo de negócios? Por que, cada vez mais, se refinam os dispositivos, os equipamentos e ampliam-se os investimentos em qualificação de pessoal com vistas à oferta de produtos e serviços ditos melhores e mais eficazes? Se essa segurança é o modo de operar contra a violência, por que não consegue eliminá-la ou reduzi-la? A mídia é contundente em afirmar que a violência vem alcançando índices alarmantes, nunca antes vistos. O segundo paradoxo: em ofertando um serviço eficiente, de resultados, as empresas deveriam estar combatendo, ou, pelo menos, reduzindo esses índices de violência que a mesma mídia que faz seus anúncios, suas propagandas denuncia o aumento, declarando, assim, subliminarmente - ou nem tanto -, que o serviço que prestam produz resultados insuficientes - ou nem os produz. Por outro lado, se, de fato, lograssem êxito no combate à violência, essas empresas teriam, a médio e longo prazo, que ter ido buscar outro nicho de mercado, ao contrário do que, na realidade, fizeram, que foi expandir seus negócios. 
Na realidade, o que se flagra é a intensificação, a ampliação avassaladora do mercado da violência pela via de sua contra face: a segurança. Diversificam-se meios, instrumentos e tecnologias que se colocam, a cada dia, no circuito do mercado, à disposição do conjunto de pessoas que possam adquiri-los, aquecendo o comércio especializado.

É preciso, pois, pensar a violência e as ações de seu combate, dentro da lógica do sistema do capital, como bons e rentáveis negócios: um alimenta-se do outro; um sobrevive a expensas do outro. Logo, as ações que se proclamam combativas e as ações de promoção de violência são, sim, uma da outra, verso e anverso, faces de uma só moeda.

Ao fim, pelo que fazem circular em termos de capital, violência e segurança podem ser vistas, uma em relação à outra, como especular - nas acepções diversas que o vocábulo comporta: quer significando imagens inversas no espelho, quer traduzindo a ação de realizar

[...] operação comercial em que uma das partes obtém lucros acima do razoável, por abusar da boa-fé da outra, ou por tirar proveito de período de exceção, como guerras, catástrofes naturais, safra ruim etc., oferecendo produtos em falta, superfaturados. (HOUAISS, 2001, p. 1227).

As acepções encaixam-se, mostram consonância.

No que até aqui foi exposto, explicitaram-se as razões por que à violência precisa ser aderida a predicação de ineliminável, inerradicável. Mas algo ainda carece ser desvelado, desnudado, inquirido: por que a violência e tudo que a cerca e the adere ganha autonomia? Por que a violência parece ter independência, vontade, volição? São questões que apontam caminhos, ofertam luz para se reconhecer que a violência, no sistema do capital, adquire uma natureza mercantil.

\section{A VIOLÊNCIA EM SEU LUSCO-FUSCO}

É imprescindível perceber a tenuidade da linha que corta, do eixo que demarca o valor de uso e o valor de troca da mercadoria. Há uma sutileza nessa passagem que permite eclipsar, nublar a percepção simultânea dessas duas faces, dessa dupla dimensão que a violência adquire. $E$ esse estado de obnubilação não é prerrogativa, não é exclusividade da mercadoria violência; ao contrário, ele é flagrante na origem da mercadoria mesma, que já traz em sua matriz a aura de algo que diz por si, que existe por si e para si mesma, que suspende, apaga a marca das relações sociais que a produzem. Daí o alerta de Marx (1973, p. 38) para essa arriscada ilusão de enxergar as mercadorias como se fuesen objetos evidentes $y$ triviales. Ao contrário do que camuflam, somente a olho nu é que não se pode evidenciar o irrecusável caráter misterioso das mercadorias que são, de fato, objetos muy intrincados, llenos de sutilezas metafísicas y de resabios teológicos, como afirma:

El carácter misterioso de la forma
mercancia [...]. Es algo así como lo
que sucede con la sensación luminosa
de un objeto en el nervio visual, que
parece como si no fuese una excitación
subjetiva del nervio de la vista, sino la
forma material de un objeto situado
fuera del ojo. (MARX, 1973, p. 38 )

Quando Marx (1973) disseca as dimensões valor de uso e valor de troca com que a mercadoria se apresenta, ele brinda a todos com a revelação desse movimento enganoso que a faz surgir dotada de anima, com uma natureza própria, com volição, suficientemente forte para expulsar a marca humana que a gesta. Demonstra que do corpo da mercadoria viu-se repelida, expurgada toda a engenharia humana de músculos, nervos, cérebro, criatividade, humanidade enfim. A esse apagamento, a essa negativa e a essa ilusão de que o produto, de que a coisa se autogesta, caminha por si, adquire vontade, autodetermina-se, ganhando, assim, traços humanos, ele descreve como o fetiche da mercadoria.

Marx (1973, p. 39-40), metaforicamente, sintetiza o mistério da apoteose do espetáculo do grande circo de fantoches - o mundo produtor, consumidor, colecionador voraz de mercadorias - em que os bonecos desertam da mão de seus manipuladores, ocupando o lugar destes, consumando-se, assim, a tirania da coisa que se impõe por meio da evaporação da marca da ação humana, do trabalho humano - sempre presente e sempre negado na mercadoria. Retomo a passagem em que ele resume esse caráter da mercadoria:

[...] Es algo así como lo que sucede con la sensación luminosa de un objeto en el nervio visual, que parece como si no fuese una excitación subjetiva del nervio de la vista, sino la forma material de un objeto situado fuera del ojo.

$\mathrm{Na}$ precisão e concisão dessa analogia transparece o grande engodo dessa coisa a que se atribuem predicados humanos. Revela-se, aí, o lusco-fusco da mercadoria. E Marx (2006, p. $69)$, nessa intenção de desnudamento, ainda trinca o cristal da redoma em que se faz guardado esse mistério, esse enigma, ao afirmar que

O misterioso da forma mercadoria consiste, portanto, simplesmente em que elas refletem aos homens as características sociais de seu próprio trabalho como características objetivas 
dos produtos mesmos do trabalho, como propriedades naturais sociais destas coisas e, daí, reflete também as relações sociais dos produtores com o trabalho conjunto como uma relação existente fora deles, entre os objetos.

Nesse processo descrito por Marx (1973, 2006), ele deixa evidenciado como que um misto de delírio $^{1}$ e de alucinação ${ }^{2}$. Mas não só isso aponta o filósofo: ele prenuncia ademais que esse enigma entranhado na mercadoria, mesmo quando decifrado, não altera em nada o modo de apresentação, de materialização da mercadoria, esse seu existir em si, por si e para si, conforme diz:

A descoberta científica tardia de que os produtos de trabalho, na medida em que são valores, são simples expressões coisificadas do trabalho humano despendido em sua produção, faz época na história do desenvolvimento da humanidade, mas de modo algum afugenta a aparência objetiva das características sociais do trabalho. (MARX, 2006, p. 72).

O construto teórico de Marx ainda abre largas pistas para o desvelamento do lado oculto da falseada intenção de combater-se a violência. $\mathrm{O}$ discurso de combate à violência, de apelo à paz já emerge desautorizado. Esse discurso - também mercadoria posta nas prateleiras para consumo - é confrontado, a todo instante, com a crescente e ilimitada aparição de novos produtos lançados no mercado, cuja finalidade, marca, mensagem subliminar ou evidente trazem o incentivo à intolerância, o cultivo da violência. Flagra-se em um sem-número de produtos um antidiscurso da paz.

É inquestionável a existência de uma engenharia, de um aparato que se coloca como possibilidade de converter a violência em produto comercializável, já ficou aqui demonstrada. Há uma intrincada rede que opera com desmedido lucro tanto no câmbio oficial quanto no câmbio paralelo com essa mercadoria singular que é a violência, que parece até mesmo contrariar as leis de mercado: quanto mais presente, quanto mais abundante, maiores os lucros.

Sob a égide do capital, sob sua lógica, quem em sã consciência, que atue nesse mercado, promoveria sua eliminação, seu controle? Óbvio que o que vai buscar o mercado é a expansão da violência sob suas múltiplas formas de apresentação - inclusive sob a faceta de segurança -, com os mais novos e sedutores invólucros, enlevada por uma fina publicidade. O capital, também pela mercadoria violência, imprime seu ideário, sua propaganda ${ }^{3}$.

O cenário da atualidade dá bem mostra do que o sistema do capital faz com tudo o que toca; com tudo o que sua voracidade alcança. As praças de metrópoles do mundo tomadas por jovens, adultos, homens e mulheres, de quem se tenta arrancar, agora, o que restou da insaciabilidade capitalista: a dignidade. Matam-se os corpos, aniquilam-se as almas. Reprisamse, de algum modo, com volúpia perversa semelhante, as cenas assistidas na Inglaterra e nos Estados Unidos nos idos dos anos 1880 .

O sistema do capital não é apenas excludente; é também e, sobretudo, mortífero. Sua letalidade é sempre superior a quaisquer medidas acautelatórias que se pretenda tomar. Suas maiores vítimas, sempre as mesmas: os sujeitos contidos pela premência da necessidade e manietados pela mão forte do Estado que contém a todos que obstaculizam a passagem do capital, cada vez mais imaterializado, volátil.

Exatamente o Estado, cujo nascimento dá-se pela arguição da tese da potencialidade da violência humana e do temor de sua concreção, vai tornar-se parceiro, avalista desse sistema - sistema do capital - que, se demonstra, nasceu do sangue alheio e continua a alimentar-se dele tal qual um vampiro insaciável.

A violência foi o meio pelo qual o capitalismo se constituiu. Não haveria como se instaurar sob outras bases que não a força bruta. Em seu percurso nada restou sem que deixasse as marcas de ferro e fogo, suas algemas, suas amarras tatuadas nos corpos. Suas conquistas foram assentadas em territórios banhados de sangue: colonizações, guerras, extermínios físicos e culturais.

O capitalismo funda-se, expande-se, consolida-se, totaliza-se pela via irrecusável da violência; violência que, ainda por cima, é integral e multifacetadamente, convertida em lucro. Pasmem: é pelo exato intermédio do Estado que o capitalismo chega a constituir-se um modo de produzir coisas, mercadorias e viver. Um modelo civilizatório que grassa o mundo, deixando rastros de desespero, dor e sangue; um modelo econômico que devasta, sem atender a rogos, as vidas no planeta.

O sistema do capital é, indiscutivelmente, um modo violento de organizar a vida no planeta. A seu comando, tudo e todos são reordenados, classificados, catalogados, disponibilizados. E o mais grave: descartáveis. Sob a bainha de sua espada, a alma humana é, a todo tempo e em todo lugar, estrangeira de seu ser. As regras não comportam o capricho de seu existir; as esquisitices de uma possível ponderação dela provinda. A roda da vida, melhor, a roda da fortuna não se faz de suas produções, de suas cautelas.

Não é vaticínio, mas somente se fosse tornada um mau negócio, a violência poderia ser excluída do horizonte da humanidade.

Lastimável é continuar tendo que admitir que,

Sem nenhuma prova acreditamos que a paz era o estado natural e a substância do universo e que a guerra era apenas 
uma agitação temporária que ocorria em sua superfície. Reconhecemos atualmente nosso erro: o fim da guerra é simplesmente o fim desta guerra. (SARTRE, Jean-Paul)

\section{REFERÊNCIAS}

ARENDT, H. Da violência. Tradução de Maria Claudia Drummond Trindade. Brasília-DF: Universidade de Brasília, 1985. (Coleção pensamento político).

BAUMAN, Z. Vida para consumo: a transformação das pessoas em mercadoria. Tradução de Carlos Alberto Medeiros. Rio de Janeiro: Jorge Zahar, 2008.

BRECHT, B. Poemas: 1913 - 1956. 5. ed. Tradução de Paulo César Souza. São Paulo: Ed 34, 2000.

COSER, L. A. Conflito. In: OUTHWAITE, W.; BOTTOMORE, T. (Editores). Dicionário do pensamento social do século $\mathbf{X X}$. Tradução de Eduardo Francisco Alves, Álvaro Cabral. Rio de Janeiro: Jorge Zahar, 1996. p. 120-123.

Nuevos aportes a la teoria del conflicto social. Tradução de Maria Rosa Viganór. Buenos Aires: Amorrortu Editores, 1967. p. 9-127.

COSTA, J. F. Violência e psicanálise. 3. ed. Rio de Janeiro: Edições Graal, 2003.

DEBORD, G. A sociedade do espetáculo: comentários sobre a sociedade do espetáculo. Tradução de Estela dos Santos Abreu. Rio de Janeiro: Contraponto, 2007.

ÉTIENNE, J. et al. Dicionário de sociologia: as noções, os mecanismos e os autores. Tradução de Germano Rio Tinto. Lisboa (Portugal): Plátano Edições Técnicas, 1998.

HOUAISS, A.; VILLAR, M. de S. Dicionário Houaiss da língua portuguesa. Rio de Janeiro: Objetiva, 2001.

MARCONDES FILHO, C. (Org.). Dicionário de comunicação. São Paulo: Paulus, 2009.

MARX, K. Elementos fundamentales para la crítica de la economía política (borrador) 18571858. 4. ed. Tradução de Pedro Scaron. Buenos Aires: Siglo XXI Argentina, 1973. v. 1.

O capital. 3. ed. condensada. Tradução e condensação de Gabriel Deville. São Paulo: Edipro, 2008. (Série clássicos Edipro).

A mercadoria. Tradução, apresentação e comentários de Jorge Grespan. São Paulo: Ática, 2006. (Ensaios comentados).
. Grundrisse: manuscritos econômicos 18571858. Esboços da crítica da economia política. Tradução de Mario Duayer, Nélio Schneider. São Paulo: Boitempo; Rio de Janeiro: UFRJ, 2011.

MARX, K.; ENGELS, F. Obras escolhidas. São Paulo: Alfa-Ômega, [s.d.]. v.1.

MAY, R. Poder e inocência: uma análise das fontes de violência. Tradução de Álvaro Cabral. Rio de Janeiro: Jorge Zahar, 1981.

MORILLAS, J. M. M. Los sentidos de la violencia. Granada (Espanha): Editorial Universidad de Granada, 2003. (Colección monográfica "Eirene", 17).

PASQUINO, G. Conflito. In: BOBBIO, N.; MATTEUCCI, N.; PASQUINO, G. Dicionário de política. 12. ed. Tradução de Carmen C. Varriale, Gaetano Lo Mônaco, João Ferreira, Luís Guerreiro Pinto Caçais e Renzo Dini. Brasília: Editora Universidade de Brasília; LGE, 2004, v. 1. p. 225 230.

SIMMEL, G. Sociologia I: estudios sobre las formas de socialización. Madrid: Biblioteca de la Revista Occidente, 1977.

SIMON, R. I. Homens maus fazem o que homens bons sonham: um psiquiatra forense ilumina 0 lado obscuro do comportamento humano. Tradução de Laís Andrade, Rafael Rodrigues Torres. Porto Alegre: Artmed, 2009.

\section{NOTAS}

Delírio, entendido como "falsa crença, baseada em inferência incorreta sobre a realidade externa, inconsistente com a inteligência e antecedentes culturais do paciente, que não pode ser corrigida pela argumentação" (KAPLAN, H. I.; SADOCK, B. J. Compêndio de psiquiatria: ciências comportamentais - psiquiatria clínica. Tradução de Dayse Batista. Porto Alegre: Artes Médicas Sul, 1993. p. 235).

2 Alucinação definida como "percepção sensorial falsa não associada com estímulos reais externos [...]" (lbid., p. 237).

3 Acerca de propaganda, Marcondes Filho (2009, p. 291) ressalta que, embora em nossa cultura empreguemse de forma indistinta as expressões propaganda e publicidade, elas não exprimem, na essência, o mesmo significado. Como diz, "o conceito de propaganda é mais amplo: abrange tanto a difusão de valores e ideias pela publicidade quanto a propaganda política, a religiosa, os sistemas ideológicos fundados em convicções filosóficas, em estruturas de poder, em práticas sociais comunitárias". E conclui: "Sendo assim, a publicidade é uma forma de propaganda, mas esta não se limita ao caráter comercial” (p. 291). 
Rejane Batista Vasconcelos

Assistente Social

Doutora em Sociologia pela Universidade Federal do Ceará (UFC)

Professora da Universidade Federal do Ceará e da Faculdade Metropolitana da Grande Fortaleza (Fametro)

E-mail: rejanebvasconcelos@gmail.com

\section{Universidade Federal do Ceará - UFC}

Avenida da Universidade, $n^{\circ} 2853$ - Bairro Benfica CEP 60020-181 - Fortaleza - Ceará - Brasil

\section{Faculdade Metropolitana da Grande Fortaleza -}

\section{Fametro}

Rua Estelita, 500 - Centro,

60010-260 Fortaleza - CE 